\title{
Humanização na Prática Odontológica: Experiência do Programa de Atenção à Gestante
}

\author{
Garbin, Artênio José Ísper; Bino, Livia da Silva; Moimaz, Suzely Adas Saliba; \\ Saliba, Nemre Adas; Garbin, Cléa Adas Saliba; Rocha, Najara Barbosa \\ Faculdade de Odontologia da Unesp — cgarbin@foa.unesp.br
}

\begin{abstract}
A Política de Humanização do SUS enfatiza o aspecto subjetivo nas práticas de saúde, comprometendo-se com a qualidade, ambiência e melhoria do atendimento. Nesse contexto, a avaliação de programas e serviços de saúde é importante instrumento para uma readequação, principalmente na ótica do usuário.O Programa de Atenção Odontológica à Gestante constitui-se por ações educativo preventivas e de tratamento odontológico em gestantes de 11 Unidades Básicas de Saúde do município no noroeste paulista. o objetivo desse estudo foi avaliar os serviços do programa na percepção das gestantes $(n=75)$. Foi utilizado um questionário com 16 questões fechadas, contendo variáveis agrupadas em categorias: ao conteúdo das reuniões didático-pedagógicas, ao atendimento clínico, ao profissional e à infra-estrutura da clínica, foram atribuídos conceitos de ótimo a fraco; ao medo e segurança no tratamentoe ao aprendizado foram atribuídos sim ou não. a maioria considerou como ótimos o conteúdo informativo trabalhado nas reuniões didático-pedagógicas $(81,1 \%)$, o atendimento clínico $(90,6 \%), 0$ profissional quanto à apresentação pessoal, gentileza e atenção $(88,7 \%, 96,2 \%, 90,6 \%$, respectivamente) e a infra-estrutura da clínica quanto à limpeza, ventilação e conforto (92,5\%, 86,8\%, 90,6\%,respectivamente). a maioria afirmou sentir segurança (96,2\%) e não sentir medo $(86,8 \%)$ durante o tratamento, e ainda, afirmou ter aprendido conteúdos até então desconhecidos (92,5\%).Concluiu-se que os serviços e ações desenvolvidos têm obtido êxito, promovendo saúde por meio de uma prática integral e humanizada.
\end{abstract}

Garbin, Artênio José Ísper; Bino, Livia da Silva; Moimaz, Suzely Adas Saliba; Saliba, Nemre Adas; Garbin, Cléa Adas Saliba; Rocha, Najara Barbosa. Humanização na Prática Odontológica: Experiência do Programa de Atenção À Gestante. In: Anais do Congresso Internacional de Humanidades \& Humanização em Saúde [= Blucher Medical Proceedings, num.2, vol.1]. São Paulo: Editora Blucher, 2014. ISSN 2357-7282 DOI 10.5151/medpro-cihhs-10541 